AMERICAN JOURNAL OF FOOD AND NUTRITION

Print: ISSN 2157-0167, Online: ISSN 2157-1317, doi:10.5251/ajfn.2011.1.1.39.43

(C) 2011, ScienceHu $\beta$, http://www.scihub.org/AJFN

\title{
Effect of added brewers dry grain on the physico-chemical, microbial and sensory quality of wheat bread
}

\author{
Maneju Haruna, "Udobi, C.E. and Joel Ndife \\ Department of Food Technology, Kaduna Polytechnic, Kaduna \\ ABSTRACT
}

\begin{abstract}
Bread samples were baked using wheat flour substituted with milled brewers' dry grain (BDG) at levels of $5,10,15$ and $25 \%$. The bread produced from wheat flour without BDG substitution served as control. The chemical composition, functional characteristics, microbial content and sensory attributes of the products were determined to ascertain their general acceptability. Results obtained showed an increase in the range of $8 \%$ for moisture, $3.5 \%$ for fat, $1.7 \%$ for Ash, $5.45 \%$ for crude fibre, $3.07 \%$ for protein and a decrease in carbohydrate content by $20.38 \%$. Results of the functional properties analyzed showed that the water holding capacity increased with BDG substitution from $2.11(\mathrm{~g})$ to $4.79(\mathrm{~g})$ while the water binding capacity increased from $0.78(\mathrm{~g})$ to $0.90(\mathrm{~g})$. There were no differences in values for the oil holding and binding capacities obtained. The average loaf volume decreased by $41 \%$ in the BDG substituted breads while the $\mathrm{pH}$ values showed a reduction with BDG substitution, Results also showed that the bread sample without (added) BDG contained more microbes during storage than the ones with BDG. Generally, bread with BDG substitutions were nutritionally superior to normal bread while normal bread had better overall sensory scores than the BDG bread.
\end{abstract}

Keywords: Wheat Bread, Brewers' dry grain, Functional properties, Nutrient composition, Microbial quality, Sensory attributes.

\section{INTRODUCTION}

Bread is a common but important staple food made from baking dough of flour and water. Its origin dates back to the Neolithic era and is still one of the most consumed and acceptable staple in all parts of the world (Mannay and Shadaksharaswany, 2005). It has however evolved into different types with varying characteristics depending on the innovations put into the production. Innovations such as variations in the plant designs, ingredients used, and product presentation are common. These sometimes may detract from the nutritional and wholesome quality of the bread product. There is therefore, the need to continuously improve the nutritional and organoleptic attributes of bread(Potter and Hotchkiss, 2006). For example, the growing use of white flour has not only improved the aesthetic value of white bread, but has also led to the reduction in the nutritional density and fibre content when compared to bread made using whole grain cereals (Albert, 1997).

Recently, consumers' awareness of the need to eat high healthy foods - known as functional foods i.e. foods which contain ingredients that provide additional health benefits beyond the basic nutritional requirements, is increasing. Food ingredients like fibre are dietary fractions which are not digested in the small intestine but are degraded in the colon.
They are frequently used as functional ingredients to enrich different types of foods ((Rodriguez et al, 2006).

Brewer's dry grain (BDG) is the main by- product of fermentation during the beer making process. It is the residue left after the separation of the wort, which is later dried and used mainly as livestock feed ingredient (Santos et al, 2003). One of the advantages of using BDG in human diets is that the brewing process uses ingredients approved for human consumption, hence it has the potential for developing new products that can meet full health regulatory approval (Mandalari et al, 2005). BDG, therefore has a strong potential to be recycled and used as a cheap source of fiber that may provide additional functional benefits when incorporated into human diets (Stojceska and Ainsworth, 2008).

Fiber is obtained mainly from the cell walls of plant tissues. Fruits, vegetables and cereals are therefore, the principal sources of fiber in our diet. An increase in the fiber content of bread is possible by using the whole wheat grain to produce whole wheat bread or by enriching the bread with other fiber-rich-sources like Brewer's Dry Grain (BDG), in order to help attain a dietary target for fiber consumption of $30 \mathrm{gm}$ per day required for a healthy nutrition (Friedman, 1989). Dietary fibers have been shown to have beneficial 
effects in the prevention of several diseases, such as cardiovascular diseases, constipation, irritable colon, colon cancer, obesity, and diabetes (Rodriguez et al, 2006).

This paper presents the results of the study on the implications of substituting different levels of wheat flour with BDG on some of the physico-chemical properties, functional characteristics, microbial and sensory quality as well as the overall acceptability of BDG enriched bread.

\section{MATERIALS AND METHODS}

Materials: The baking ingredients were purchased from a local supermarket in kaduna-Nigeria while the Brewer's spent grain (BSG) was obtained from International Beer and Beverages Industries (IBBI) also in Kaduna- Nigeria.

Preparation of Brewers dry grain (BDG): The BSG was refrigerated immediately after collection to prevent unwanted fermentation and was subsequently washed in water a number of times to remove unwanted debris and aroma and then dried in a cabinet drier until it was suitable for milling. The dried sample known as brewers dried grain (BDG) was later milled, sieved, packed in sealed polyethylene bags and stored at room temperature until used.

Bread Making:The ingredients used were a percentage of the flour, BDG (of various percentages), water (55\%), Salt $(0.9 \%)$, Sugar $(8.3 \%)$, baking fat $(10 \%)$, and yeast $(0.25 \%)$, were blended in a mixer and the resulting dough was molded and placed in a pre-oiled baking bowl. The dough was proofed for $45-60$ minutes at $35^{\circ} \mathrm{C}$ and $85 \%$ relative humidity and baked in a Reel oven for 35 minutes at $217^{\circ} \mathrm{C}$.

A control sample of normal bread with 0\% BDG substitution was made and labeled sample A, along with five other samples of wheat bread with substitution levels of BDG at $5 \%, 10 \%, 15 \%, 20 \%$ and $25 \%$, which were labeled as samples; B, C, D, E, and $F$, respectively, were used for the study.

Chemical Analysis: The determination of the chemical composition of the bread samples viz: moisture content, ash content, protein content, fat content, crude fiber and carbohydrate content were carried out as described by AOAC (1990).
Functional Properties Analysis: The functional properties of the breads viz: the water holding capacity (WHC), water binding capacity (WBC); oil holding capacity $(\mathrm{OHC})$ and oil binding capacity (OBC) were determined using methods described by AACC(2000) with modifications

The loaf volume and loaf volume index were measured by the seed displacement method as described by Ayo et al, (2008).

The $\mathrm{pH}$ and brix of the BDG-bread samples were measured using the $\mathrm{pH}$ meter and refractometer as described by Jacobs (1999).

Microbiological Assay: The determination of the microbial contamination (mesophilic aerobic bacteria, yeast and mold counts) in the products was performed by the method outlined in compendium of methods for the microbiological examination of foods (AMPH, 1992) with some modifications.

Sensory Analysis: Sensory evaluation of the BDG bread samples were carried out by 20 panelists on a 9 point hedonic scale for different parameters such as color, aroma, taste, texture and overall acceptability as described by Ihekoronye and Ngoddy (1985).

Statistical Analysis: The sensory evaluation data was statistically analyzed using the analysis of variance (ANOVA) and the Duncan Multiple range test with significance level at $p<0.05$ (Ihekoronye and Ngoddy, 1985).

\section{RESULTS AND DISCUSSION}

Effect of BDG addition on Chemical Composition: The results of the proximate analysis of the bread samples are presented in Table 1.

The proximate values for moisture, ash, fat, crude fiber and protein, were lowest in normal bread of sample A, and higher in other BDG added samples. The proximate values increased with increasing levels of BDG substitutions except for carbohydrate content which showed a reverse. The carbohydrate content was highest in sample A (58.28\%) and lowest in sample $F(34.95 \%)$.

The BDG inclusion must have caused a variation in the chemical composition of the bread samples produced. BDG has been shown to have high content of protein, fiber, ash, and fat than refined wheat flour, 
while the latter is higher in carbohydrate content (Mandalari et al, 2005).

The chemical composition of any food is an indication of the nutritional quality of the food. BDG is an important source of dietary fiber containing arabinoxylan, xylose and arabinose (Santos et al, 2003). The addition of BDG into dough formulation have been shown by Stojceska and Ainsworlt (2008) to significantly improve the dietary fiber content and minerals content of baked products.

\section{Effect of BDG on Physical Properties}

Table1: Proximate composition of the formulated breads.

\begin{tabular}{|c|c|c|c|c|c|c|}
\hline SAMPLE & $\begin{array}{c}\text { MOISTURE } \\
(\%)\end{array}$ & $\begin{array}{c}\text { ASH } \\
(\%)\end{array}$ & $\begin{array}{c}\text { FAT } \\
(\%)\end{array}$ & $\begin{array}{c}\text { CRUDE } \\
\text { FIBRE } \\
(\%)\end{array}$ & $\begin{array}{c}\text { PROTEIN } \\
(\%)\end{array}$ & $\begin{array}{c}\text { CARBOHYDRATE } \\
(\%)\end{array}$ \\
\hline $\mathrm{A}$ & 26.50 & 0.97 & 1.5 & 1.64 & 11.11 & 58.28 \\
\hline $\mathrm{B}$ & 31.00 & 1.33 & 2.0 & 2.24 & 12.34 & 51.09 \\
\hline $\mathrm{C}$ & 31.50 & 1.66 & 2.0 & 3.98 & 12.69 & 48.73 \\
\hline $\mathrm{D}$ & 32.97 & 1.99 & 2.5 & 3.42 & 13.65 & 44.91 \\
\hline $\mathrm{E}$ & 33.97 & 2.33 & 3.0 & 6.02 & 14.18 & 40.50 \\
\hline $\mathrm{F}$ & 35.00 & 2.67 & 5.00 & 7.09 & 15.28 & 34.95 \\
\hline
\end{tabular}

Key: Sample A = Bread without BDG addition

$\mathrm{B}=$ Bread with $5 \% \mathrm{BDG}$ addition

$\mathrm{C}=$ Bread with $10 \% \mathrm{BDG}$ addition

$\mathrm{D}=$ Bread with $15 \%$ BDG addition

$\mathrm{E}=$ Bread with $20 \%$ BDG addition

$\mathrm{F}=$ Bread with $25 \%$ BDG addition

Table 2: Functional Characteristics of the formulated Bread Samples

\begin{tabular}{|l|c|c|c|c|c|c|}
\hline BDG & A & B & C & D & E & F \\
\hline Water holding (g) & 4.79 & 4.34 & 2.96 & 2.79 & 2.17 & 2.11 \\
\hline Oil holding (g) & 1.37 & 0.29 & 0.48 & 1.96 & 1.65 & 1.35 \\
\hline Water binding (g) & 0.78 & 0.78 & 0.83 & 0.87 & 0.88 & 0.90 \\
\hline Oil binding (g) & 0.78 & 0.70 & 0.88 & 0.78 & 0.69 & 0.67 \\
\hline Loaf volume $\left(\mathrm{cm}^{3}\right)$ & 1280 & 1280 & 966 & 770 & 750 & 750 \\
\hline Loaf volume index $\left(\mathrm{cm}^{3} / \mathrm{g}\right)$ & 484.9 & 421.4 & 460.7 & 502.5 & 524.0 & 507.8 \\
\hline Ph & 4.95 & 4.79 & 4.93 & 4.81 & 4.74 & 4.62 \\
\hline${ }^{0}$ brix & 1.20 & 1.1 & 0.80 & 0.50 & 0.21 & 0.20 \\
\hline
\end{tabular}

Table3: Microbial Analysis (Total aerobic bacteria counts).

\begin{tabular}{|c|l|l|l|}
\hline SAMPLE & $\begin{array}{c}\text { DAY 1 } \\
\text { APC (cfu/g) }\end{array}$ & $\begin{array}{c}\text { DAY 3 } \\
\text { APC (cfu/g) }\end{array}$ & $\begin{array}{c}\text { DAY 6 } \\
\text { APC (cfu/g) }\end{array}$ \\
\hline A & Spread & Spread & $7.7 \times 10^{2}$ \\
\hline B & $3.7 \times 10^{2}$ & $4.1 \times 10^{2}$ & $3.4 \times 10^{2}$ \\
\hline C & $2.0 \times 10^{2}$ & $1.7 \times 10^{2}$ & $2.9 \times 10^{2}$ \\
\hline D & $2.2 \times 10^{2}$ & $1.8 \times 10^{2}$ & $3.6 \times 10^{2}$ \\
\hline E & $<1.0 \times 10^{2}$ & $<1.0 \times 10^{2}$ & $2.3 \times 10^{2}$ \\
\hline F & $<1.0 \times 10^{2}$ & $1.4 \times 10^{2}$ & $3.0 \times 10^{2}$ \\
\hline
\end{tabular}

$\mathrm{APC}=$ Aerobic plate count, $\mathrm{CFU}=$ coliform forming unit
The results of the analysis of the functional characteristics of the samples are given in table 2.

The data on WHC and WBC presented, showed some variations in values as a result of additions of

BDG. Normal bread sample A, had the highest WHC of $4.79(\mathrm{~g})$ while sample $F$, with the highest BDG inclusion had the lowest WHC of 2.11(g). The reverse was the case for WBC. The WBC of normal bread sample $A$, gave the lowest value of $0.78(\mathrm{~g})$. The highest WBC was recorded in BDG sample $E$ with $0.88(\mathrm{~g})$. 
The $\mathrm{pH}$ of the samples showed a decrease with increasing levels of BDG substitution. The lowest $\mathrm{pH}$ value was recorded in sample $F,(4.62)$ with highest BDG inclusion. The $\mathrm{pH}$ influence on the microbialecology will determine the surviving microbes which will ultimately affect the shelf stability and sensory properties of the products. (Ezeama, 2007).

The sugar content of sample $F$, with highest BDG was lowest with $0.2^{\circ}$ brix value. Brewers spent grain used had $0^{\circ}$ brix. Hence bread samples with higher BDG have lesser sugar content, which could be potentially useful in diabetic diets.

There was a gradual reduction of loaf volume with increase in BDG content. The normal bread, sample $A$, had the highest volume of $1280 \mathrm{~cm}^{3}$ in contrast to the bread sample $F$ with highest BDG substitution $\left(750 \mathrm{~cm}^{3}\right)$.

The deleterious effects of addition of fiber on dough structure and loaf volume have been suggested to be due to the dilution of gluten network, which in turn impairs gas retention rather than gas production (Eiman et at, 2008). These results were comparable to those of Stojeska and Ainsworth (2008), where Arabinoxylans the most important dietary fiber component in BDG seems to be the main contributor for decreasing loaf volume.

Effect of BDG on the Microbial Quality: The results of microbial analysis of the bread samples are presented in tables 3 and 4.

The microbial analysis carried out during the 6 days of shelf life study indicates that the total aerobic bacterial counts in the BDG formulated bread Table 5: Result of Sensory Evaluation

\begin{tabular}{|c|c|c|c|c|c|}
\hline SAMPLE & Colour & Taste & Aroma & Texture & Acceptability \\
\hline A & $8.7^{\mathrm{a}}$ & $8.6^{\mathrm{a}}$ & $8.5^{\mathrm{a}}$ & $8.6^{\mathrm{a}}$ & $8.6^{\mathrm{a}}$ \\
\hline B & $7.4^{\mathrm{b}}$ & $7.2^{\mathrm{b}}$ & $7.5^{\mathrm{b}}$ & $7.5^{\mathrm{b}}$ & $7.6^{\mathrm{b}}$ \\
\hline C & $6.9^{\mathrm{c}}$ & $7.1^{\mathrm{c}}$ & $6.6^{\mathrm{c}}$ & $6.9^{\mathrm{c}}$ & $6.5^{\mathrm{c}}$ \\
\hline D & $6.5^{\mathrm{d}}$ & $6.6^{\mathrm{c}}$ & $6.1^{\mathrm{d}}$ & $6.6^{\mathrm{d}}$ & $4.5^{\mathrm{c}}$ \\
\hline E & $6.1^{\mathrm{c}}$ & $6.4^{\mathrm{d}}$ & $5.8^{\mathrm{c}}$ & $6.4^{\mathrm{c}}$ & $2.7^{\mathrm{c}}$ \\
\hline F & $5.9^{\mathrm{d}}$ & $5.8^{\mathrm{c}}$ & $3.4^{\mathrm{i}}$ & $5.8^{\mathrm{i}}$ & 0.74 \\
\hline LSD & 0.94 & 0.43 & 0.99 & 0.74 & \\
\hline
\end{tabular}

Mean values in the same column carrying the same alphabet are not significantly different while those carrying different alphabet are significantly different. $(p<0.05)$.

The statistical analysis revealed that there were significant difference $(p<0.05)$ among all the bread samples produced in the sensory characteristics observed. The control sample with $0 \%$ BDG substitution gave the highest scores (8.6) for all the samples range from $<1.0 \times 10^{2}$ to $4.1 \times 10^{2} \mathrm{cfu} / \mathrm{g}$. While the highest aerobic bacteria counts $\left(7.7 \times 10^{2} \mathrm{cfu} / \mathrm{g}\right)$ were observed in the normal bread sample $A$, on the $6^{\text {th }}$ day of storage.

There were no observable mould and yeasts in the BDG samples during the 6 days of shelf study however, mould counts of $<1.0 \times 10^{2} \mathrm{cfu} / \mathrm{g}$ were seen in the normal bread sample $A$, on the $6^{\text {th }}$ day of shelf study.

The fibre content and the $\mathrm{pH}$ of BDG bread samples could have been responsible. Fibers unlike sugars (as shown by the brix) are not readily nutritionally utilized, but only through fermentation by specific microbes. The low $\mathrm{pH}$ values may also confer an acidic environment on the BDG-bread samples which is not suitable for mesophilic microbial growth (Ezeama, 2007).

Table 4: Microbial analysis (Total Yeast and Mould counts)

\begin{tabular}{|c|c|c|c|}
\hline SAMPLE & $\begin{array}{c}\text { DA1 } \\
\text { APC (cfu/g) }\end{array}$ & $\begin{array}{c}\text { DAY 3 } \\
\text { APC (cfu/g) }\end{array}$ & $\begin{array}{c}\text { DAY 6 } \\
\text { APC (cfu/g) }\end{array}$ \\
\hline A & Nil & Nil & $<1.0 \times 10^{2}$ \\
\hline B & Nil & Nil & Nil \\
\hline C & Nil & Nil & Nil \\
\hline D & Nil & Nil & Nil \\
\hline E & Nil & Nil & Nil \\
\hline F & Nil & Nil & Nil \\
\hline
\end{tabular}

$\mathrm{APC}=$ Aerobic plate count, $\mathrm{CFU}=$ coliform forming unit

Effect of BDG on Sensory Evaluation: Results of sensory evaluation of bread samples containing different level of BDG- substitution as compared to the control is shown in Table 5 . 
The darker color of the crumbs was reported by Hu et al (20097) to be directly related to the increase in fiber content. The scores for texture (softness and chewiness) of the bread samples, decreased with increase in BDG-substitution as reported by Stojcesk and Ainswort (2008).

Hard Crumb texture, caused by increased fiber from wheat bran substitution was reported by Eiman et al (2008). It has also been reported that the pentopans component of BDG fibre may cause hardening by cross linking gluten proteins (Autio et al, 2005).

BDG substituted breads are known to have fermentation odours and flavours. This could be responsible for their poor scores. The sensory evaluation also revealed that breads with BDG substitution up to $15 \%$ were overall acceptable, even though normal bread was still preferred.

\section{CONCLUSION:}

In conclusion, bread with BDG substitution were found to be nutritionally superior (has higher protein, fat and crude fibre content) to normal bread. However the scores for sensory parameters like taste, aroma, texture (mouth feel), except for color, were generally inferior to that of normal bread. Therefore, normal bread had better overall acceptability scores than the BDG breads.

Further research work focused on how to improve the organoleptic qualities and hence acceptability of BDG enriched bread is encouraged.

\section{REFERENCES}

AACC. (2000). Approved Methods of Analysis. (10 ${ }^{\text {th }}$ ed.). The American Association of Cereal Chemists St. Paul, Minnesota.

Akhtar, S., Anjum, F., Rehman, S., Sheikh, M. and Farzena, K. (2008). Effect of fortification on the physico - chemical and microbiological stability of whole wheat flour. Food chemistry $110: 113-119$.

Albert, R. D. (1997). Bakery Materials and methods. (4 ${ }^{\text {th }}$ ed.). Macmillian Publishers, London. P. 110 - 106.

AMPH. (1992). Compendium of methods for the microbiological examination of foods. Washington DC: American Public Health Association.

AOAC. (1999). Official Methods of analysis. (15 ${ }^{\text {th }}$ ed.). Association of Official Analytical Chemists. Washington, DC.

Autio, K., Kruus, K., Knaapila, A., Gerber, N., Flander, L. and Buchert, J. (2005). Kinetics of transglutaminase induced cross linking of wheat proteins in dough.
Journal of agricultural food chemistry, 53: 1039 1045.

Ayo, J., Nakama, I., Haruna, S., Bitrus, Y., and Onajaife, F. (2008). Effect of dough improvers on the physical and sensory quality of acha (Digitaria exilis) flour bread. Nigeria food journal, 26 (1): 101-105.

Eimam, H., Amir, M. and Mustafa, A. (2008). Effect of Fermentation and particle size of wheat bran on the antinutritional factors and bread quality. Pakistan Journal of Nutrition, 7(4): 521 - 526.

Ezeama, C. F. (2007). Food Microbiology: Fundamentals and Applications. Natural Prints Ltd. Lagos.

Friedman, G. (1989). Nutritional Therapy of Irritable Bowel Syndrome. American Journal of Clinical Nutrition, P. $515-524$.

Hu, G. H., Yang, F., Ma, Z. and Zhou, Q. (2007). Development of Research and application of rice bran dietary fibre. China Food Additives, 84 (5) : 80-85.

Ihekoronye, A. I. and Ngoddy, P. O. (1985). Integrated Food Science and Technology for the Tropics. ( $2^{\text {nd }}$ ed.). Macmillan Publishers Ltd., London.

Jacobs, B. M. (1999). The Chemical Analysis of Foods and Food Products. ( $3^{\text {rd }}$ ed.) CBS Publishers and Distributors. New Delhi, India.

Mandalari, G., Faulds, C., Sancho, A., Saija, A., Bisignsno, G., Locurto, R. and Waldron, K. (2005). Fraction and Characterization of Arabinoxylans from brewers' spent grain and wheat bran, Journal of Cereal Science, 42, $205-212$.

Mannay, S. and Shadaksharaswany C. M. (2005). Foods: Facts and Principles. ( $2^{\text {nd }}$ ed.). New Age International Ltd. Publishers. New Delhi, India.

Nassar, A. G., Abdel-Hamied, A. A. and El-Naggar, E.A. (2008). Effects of Citrus by products on the chemical, Rheological and Organoleptic characteristics of Biscuits. World Journal of Agricultural Sciences, 4 (5): $612-616$.

Potter, H. and Hotchkiss, I. (2006). Food Science.( $5^{\text {th }}$ ed.). CBS Publishers and Distributors. New Delhi, India.

Rodriguez, R., Jimenz, A., Fernandex-Bolanos, J., Guillen, R. and Heredia, A. (2006). Dietary fiber from vegetable products as source of functional ingredients. Trends in Food Science and Technology, 17, 3 - 15.

Rosell, C.M., Royas, J. A. and Benedito, D. B. (2001). Influence of hydrocolloids on dough rheology and bread quality. Food hydrocolloids, 15: $75-81$.

Santos, M., Jimenez, J., Bartolome, B., Gomez-Cordoves, C., and Nozal, M. J. (2003). Variability of brewers spent grain within a Brewery. Food Chemistry, 80, 17 21.

Stojceska, V. and Ainsworth, P. (2008). The effect of different enzymes on the quality of high fibre enriched brewer's spent grain breads. Food Chemistry, 110: $865-872$. 